THURSDAY, DECEMBER 4, I89o.

\section{THE COUNTY COUNCILS AND TECHNICAL EDUCATION.}

A CONFERENCE will be held to-morrow under $A$ the auspices of the National Association for the Promotion of Technical and Secondary Education, which may prove of the greatest importance to the future development of education in this country. The Marquis of Hartington will be in the chair, and representatives of County and County Borough Councils and other Local Authorities working the provisions of the Technical Instruction Act have been invited to meet the Executive Committee of the Association and delegates from its Branches throughout the country, to confer on the best means of utilizing the new fund placed at the disposal of County Councils under the Local Taxation Act of this year for the purpose of education.

It will be remembered that, by the accident of the abandonment of the licensing clauses of the Local Taxation Bill, a sum of about $\Varangle 743,000$, the residue of the proceeds of the new beer and spirits duty after defraying the charges for police superannuation, has been allotted to County Councils in England and Wales, with permission to apply the fund to technical education, or, in the case of Wales, to intermediate education under the Welsh Intermediate Education Act. The Scotch share, amounting to another $£ 50,000$, may be used for the purpose of the Scotch Technical Schools Act.

A number of reflections are suggested by this unexpected appropriation. Wales is ahead of England and Scotland in the matter, because a more complete Act is in force in the Principality. The Welsh may use the fund to organize their secondary education under public control, while in England such organization, though, as has been pointed out, ${ }^{1}$ not impossible, has to be carried out on a far more restricted scale and under more hampering conditions. This is not because the English share of the fund is inadequate, but merely because when the critical moment for the appropriation came it found Wales provided with the necessary machinery, in the shape of the Intermediate Education Act which is unfortunately not yet in force in the rest of the Kingdom. It was too late in the session to build up the requisite machinery for England, so we are compelled to wait.

Had it not been for the passage of the Technical Instruction Act of 1889 , which, as will be remembered, was fiercely contested at the time by many of the more extreme educational partisans, there would have been no machinery at all in England for the utilization of the new fund for education, and the whole would doubtless have been allotted to other purposes, such as reduction of rates. As it is, the fund can be administered under the provisions of that Act, incomplete as it is, until it is duly amended by the Bill of which Sir Henry Roscoe has already given notice, and by the extension to England, under a somewhat modified form, of the Welsh Intermediate Education Act. Thus, had it not been for the previous passage of a confessedly imperfect measure,

"See "Suggestions to County Councils" (National Association for the Promotion of 'Technical and Secondary Education, 14 Dean's Yard).

NO. I IOI, VOL. 43] the greatest chance yet offered for the organization of secondary education would have been missed altogether. We hope this fact will be remembered when heated advocates of one line or other of educational policy are again tempted to forget that "half a loaf is better than no bread." Get public supervision of higher education recognized in an Act of Parliament, and all the rest will surely follow. The Act may be imperfect; parts of it may be bad; but he is a pedant who refuses it on that ground. The Act will be amended as necessity arises; new powers of control will be acquired when any power of control has been once conceded. The new Act gives increased facilities for the organization of education to various parts of the Kingdom in precise proportion to the powers already possessed. "To him that hath shall be given," in education as in other matters.

So much for the Act. The next question that arises is its administration by the local authorities, who, it is to be observed, have power to devote all or any part of the fund to education, and of course to use the rest for the relief of rates. It must be admitted that it is a great temptation, to some County Councils at least, to take advantage of their undoubted right to use the fund otherwise than Parliament intended; but it is a temptation which should be resisted if only for the reason that the renewal of the grant next year may largely depend on the use which can be shown to have been made of it by local authorities. It would be suicidal policy, even for the strictest friend of the ratepayer, to clutch the money this year for the relief of rates, and thus to lose permanently a grant which will be sorely needed before long in order to meet the new charges which, as Mr. Goschen hinted, are likely to be put upon local authorities with respect to agricultural and intermediate education.

So far as the matter has yet come before County Councils, there is no cause for discouragement. At least nine counties have already determined to use the whole or part of the money for technical education; others have appointed committees to inquire into the whole question. We hope that the result of the Conference which is announced will be to decide many wavering Councils to take the same course.

There will be plenty for the Conference to discuss. The work of organizing technical education is new to County Councillors, and many of them are still quite in the dark on many points. Moreover, practical difficulties have arisen in some districts in the working of the Act, on which it will be useful to compare notes. We have received a copy of the provisional agenda, by which we see that among other things the meeting will discuss the nature of the preliminary proceedings which should be taken by County Councils which are desirous of assisting education out of the new fund. This is an important question. Should the Councils simply pass a resolution inviting applications for assistance, and then judge among the various qualified institutions which send in claims? Or should they institute an inquiry into the state of education in their districts, and on the results of that inquiry formulate a comprehensive scheme? Should the money be devoted chiefly to the assistance and development of existing institutions? Or should the Councils initiate schools of their own under the general powers conferred by the Act? On matters like this many 
Councils are doubtless waiting for a lead such as they may obtain at the Conference. Meanwhile we may commend to their attention the carefully drawn report just presented to the Shropshire County Council by the Technical Instruction Committee of that Council, as a model in many ways of what such a report should be.

The Conference will also discuss the modes in which the fund may be divided among the non-county boroughs and sanitary districts within the county. This again, is a debatable question. Should the basis of the allotment be rateable value, or population, or existing local effort? How far should the convenience and needs of the county as a whole be exclusively consulted in the scheme, independently of the wishes or claims of particular localities? Clearly the Act gives no legal claim to a non-county borough on any particular proportion of the money, though the County Council may, if it please, act through these minor authorities in the distribution. The question is eminently one on which light will be thrown by a friendly conference.

The third point for discussion is the amendment of the Technical Instruction Act. Certain difficulties have arisen in the administration of the Act, which may be removed without raising controversies. For example, many Councils wish to aid agricultural education by founding or assisting agricultural schools in county boroughs in their district. But this they may not do, for the county boroughs are outside their jurisdiction; while the county boroughs themselves are not likely to do the work, since it will, as a rule, be useless to their own inhabitants. Other points, such as the question of the provision of scholarships, especially to schools outside the counties, have been called in question, and need settlement.

The fourth subject on the agenda is the most important of all; viz. the best mode of assisting intermediate and agricultural education. It is hardly to be expected that the members of the Conference will succeed in evolving a complete plan; but they will do a great service if they demand, with no uncertain voice, the extension to England of a measure based on that which is working so admirably in Wales. Meanwhile, the question of the best mode of assisting intermediate education depends very greatly on the chance of the future renewal of the grant. We look to Lord Hartington to give an assurance that there is no possibility of the diversion of any part of the new fund by the Government to other purposes than technical and secondary education.

\section{DREYER'S LIFE OF TYCHO BRAHE.}

Tycho Brahe: a Picture of Scientific Life and Work in the Sixteenth Century. By J. L. E. Dreyer, Ph.D., F.R.A.S. (Edinburgh: A. and C. Black, I 890.)

THE time had evidently come for the publication of an adequate account of the life and work of the great Danish astronomer. Popular presentments of the first, and partial studies relating to the second, there have been, it is true, in more languages than one; but Gassendi's was, until now, the only scientific biography of Tycho Brahe; and numerous documents, inedited and inaccessible in 1654 , have since been brought to light, clearing up much that was obscure, supplementing meagre with full information, and thus rendering possible the virtually complete narrative now given to the public by Dr. Dreyer. That unstinted pains were bestowed upon his task is obvious from the manner of its accomplishment; and he was equipped for it with a combination, desirable rather than usual, of linguistic, historical, and scientific attainments. Indeed, at times, superabundant information is afforded; the wealth of details tends to congestion; the essential does not decisively enough maintain its supremacy over the superfluous. The book is none the less a most valuable contribution to the history of mediæval astronomy; it is creditably exempt from slips and inaccuracies of memory, pen, or print; abounds with bibliographical knowledge and indications; and-not its least merit-is furnished with a highly serviceable index. It portrays, moreover, with perfect candour, yet full comprehension and sympathy, a vigorous and picturesque individuality.

Judgment in forming, and persistence in holding to, a large and definite purpose, rather than surpassing intellectual ability, caused Tycho Brahe to tower above his scientific contemporaries. Wittich-to say nothing of Viète and Harriot-was his superior in mathematics; he could lay no claim to the inven tive ingenuity of Joost Büroi ; his system of the world was less plausible than that of the uncouth Reymers. But he saw clearly what was indispensable to the progress of astronomy, and by the undaunted energy of his efforts to supply it, raised himself to the high level of his great undertaking.

Intil observations were begun at Uraniborg, the astronomy of the ancients, as Dr. Dreyer says with truth, reigned practically undisturbed. A speculative impulse of incalculable importance had indeed been given by the promulgation of the Copernican doctrine; but

"No advance had been made in the knowledge of the positions of the fixed stars, those stations in the sky by means of which the motions of the planets had to be followed; the value of almost every astronomical quantity had to be borrowed from Ptolemy, if we except a few which had been redetermined by the Arabs. No advarice had been made in the knowledge of the moon's motion, so important for navigation, nor in the knowledge of the nature of the planetary orbits, the uniform circular motion being still thought not only the most perfect, but also the only possible one for the planets to pursue. Whether people believed the planets to move round the earth or round the sun, the complicated machinery of the ancients had to be employed in computing their motions, and, crude as the instruments in use were, they were more than sufficient to show that the best planetary tables could not foretell the positions of the planets with anything like the desirable accuracy.

"No astronomer had yet made up his mind to take nothing for granted on the authority of the ancients, but to determine everything himself. Nobody had perceived that the answers to the many questions which were perplexing astronomers could only be given by the heavens, but that the answers would be forthcoming only if the heavens were properly interrogated by means of improved instruments capable of determining every astronomical quantity anew by systematic observations. The necessity of doing this was at an early age perceived by Tycho Brahe. . . . By his labours he supplied a sure foundation for modern astronomy, and gave his great successor, Kepler, the means of completing the work commenced by Copernicus" ("Tycho Brahe," p. 9).

NO. I IOI, VOL. 43] 